\title{
EL ARQUITECTO DE LA CATEDRAL DE CUZCO, PERU
}

\author{
POR \\ MANUEL TOUSSAINT
}

REFIERE don Eugenio Llaguno y Amírola en sus ya clásicas "NotiR cias", que el mejor arquitecto que pasó a América fué Francisco Becerra, quien llegó a Nueva España en el cortejo del Lic. Granero de Arévalo y que, después de haber ejecutado muchos trabajos en la Nueva España, pasó a Sudamérica, donde hizo otras construcciones y llegó a trazar, por orden de don Martín Linriquez, las catedrales de Lima y del Cuzco, comenzando por esta última y siguiendo con la otra ya muerto su protector.

La afirmación de Llaguno ha sido puesta en duda por los eruditos peruanos y por el crítico de arte argentino Arquitecto Mario J. Blischiazzo, funclándose eil que las investigaciones del Doctor José Uriel García aclararon que el arquitecto habia sido el vizcaino Juan Manuel de Veramendi, llamado expresamente de Chuquisaca para trazar la obra y dirigir la construcción.

Para corroborar el error de Llaguno, el Arquitecto Buschiazzo hace referencia al hecho de que el maestro Alonso Rodriguez no fué el autor 
de la Catedral de Santo Domingo, como lo demostró Antonio Muro Orejón al encontrar el testamento del maestro Rodríguez, en el que sostiene que nunca estuvo en América. De este hecho saca la consecuencia de que la obra de Ilaguno, "básica y fundamental en lo que se refiere a la arquitectura española, adolece de cierta ligereza en las afirmaciones que formula respecto a América".

Indudablemente que la equivocación sufrida por Llaguno en el caso del maestro Rodríguez no amerita el cargo de ligereza que le hace mi querido amigo Buschiazzo, pues creo yo que cualquier erudito que hubiese encontrado el contrato auténtico que publica L,laguno, hubiese sufrido el mismo error, ya que en dicho contrato no se especifica, como en algunos otros, "que no pasó" o no se llevó a efecto.

Pero veamos si la misma critica puede aplicarse al caso de Becerra. En la página 58 del tomo III de las "Noticias", dice Llaguno que Becerra hizo en Lima, ante el Lic. Francisco de Cárdenas, Alcalde de aquella Audiencia Real, el 3 de abril de 1585, una Información que existe en el Archivo General de Indias, de la cual ha sacado todas las noticias que da en su libro, "omitiendo otras muchas relativas a este gran profesor y a sus obras en España e Indias". Verdadera desgracia es que Liaguno no haya agotado todas las noticias que acerca de Becerra vió en la información levantada por el propio arquitecto, y es una deuda que tienen para con nosotros los eruditos españoles, que deben localizar cuanto antes y publicar debidamente ese escrito que tantos puntos aclarará en nuestra Historia Arquitectónica del siglo XVI.

De manera que si el propio Becerra es quien afirma que él comenzó a construir la catedral del Cuzco, debemos suponer que algo haya de verdad en el fondo $y$, por otra parte, estamos ya acostumbrados a que en los orígenes de nuestros templos, sobre todo las catedrales, aparezcan los nombres de varios artífices. Sin ir más lejos, grandes han sido las disctsiones para poder fijar quiénes fueron los arquitectos de nuestras dos catedrales máximas: la de México y la de Puebla. A propósito de esta última, el documento que publica Llaguno le da el mérito incontrovertiblemente al mismo Francisco Becerra; pero aún hay quien siga pensando en Juan Gómez de Mora. De manera que yo creo que no debe ser descartado de plano el nombre de Becerra con relación a la catedral de Cizzco, y para sostener esta hipótesis me fundo, no sólo en este documento histórico, sino en el estudio mismo del templo cuzquerho, comparándolo con la catedral de Puebla, de que, como hemos dicho, fué autor nuestro arquitecto. Los planos son semejantes, atuque esto no haga gran fuerza, 
pues casi todas las plantas de las catedrales americanas presentan parecido, como que derivan de las últimas catedrales renacientes europeas. Mas la identidad entre las plantas de ambas catedrales se acentúa al grado de que puede decirse que es la misma con las siguientes diferencias: la capilla real o altar llamado de los Reyes se encuentra en el templo angelopolitano limitado por dos muros, de manera que forma un ábside rectangular a la iglesia, en tanto que en la catedral cuzqueña el ábside ocupa todo el testero del edificio; la planta regular de la catedral poblana se ve dislocada en la del Cuzco en su ángulo del oriente, para formar la sacristía; lo cual es evidentemente un defecto; la catedral de Puebla presenta siete capillas por banda, en tanto que la del Cuzco tiene siete en la nave del Evangelio y sólo cinco en la de la Epístola; el primer tramo de la catedral cuzqueña que corresponde al trascoro, es mucho más amplio que los otros, igual al del crucero, en tanto que en la catedral de Puebla son dos tramos los que se encuentran atrás del coro; los cubos de las torres en la catedral de Puebla albergan capillas, en tanto que en el Cuzco, por razones de solidez sin duda, sólo alojan en su centro las escaleras; la catedral sudamericana no presenta ni crujía ni "ciprés".

Fuera de las plantas hay semejanza en las torres de ambos templos: el primer cuerpo de las torres de la catedral de Puebla es semejante al único que forma las torres de la catedral del Cuzco y estas torres cuzqueñas sin duda han servido de modelo para los demás templos de la capital incaica. Constan simplemente de estructuras apilastradas con su entablamiento completo, campaniles con arco de medio punto, cornisa vigorosa, un ático que en la catedral poblana es balaustrada y pináculos prolongando las pilastras; cupulines iguales, los de Puebla con una linternilla, y los cuzqueños sin ella. Todo el templo estí coronado de pinácuIos que en la catedral poblana son piramidales de vivo sabor herreriano, en tanto que en la catedral del Cuzco aparecen perillones y almenas. A este respecto, hay que observar que es la catedral del Cuzco casi el único templo de Sudamérica que recuerda las iglesias almenadas que se levantaron en México durante el siglo XVI.

Pero la semejanza más importante entre ambas iglesias, que por sí sola bastaría a hacer sospechar la presencia de un mismo arquitecto en ambas, es la disposición de la bóvedas. Suponemos que la techumbre de la catedral peruana es la original, fundándonos en que todavía es el viejo sistema de bóvedas nervadas que en México se usó abundantemente durante la primera centuria del virreinato, y que indudablemente tuvo gran auge en Sudamérica, por más que la mayor parte de las bóvedas 
construidas en tal forma haya desaparecido; es indudable que en el proyecto de Becerra para la catedral de Puebla, se trazaban bóvedas semejantes; pero lo más curioso es que el proyecto poblano presentaba las bóvedas exactamente en la misma disposición en que están construidas las de la catedral cuzqueña, es decir, las de las tres naves centrales a una misma altura y las de las capillas más bajas, para poder dar luz al edificio. Se forma así, como observa el arquitecto Buschiazzo, un templo salón. Exactamente igual era el proyecto de Becerra para la catedral poblana, pues cuando el señor Obispo Palafox reanucló los trabajos de su catedral, en un informe acerca de la construcción, dice: "Reconocióse que iba errada su obra, porque siendo de cinco naves con las capillas, iban las tres principales a un peso con que quedaba baja, obscura y desproporcionada. Por esto se alzó la nave mayor y las colaterales y cada una recibe luz por sí misma, con que quedó alta y clara, hermosa y proporcionada". De fijo que para hacer esta reforma el señor Palafox tenia ya presente a la catedral de México, que para estas fechas — 1640- iba ya muy adelantada, pero es indudable que el proyecto anterior era el de Becerra, que fué realizado integtamente en la catedral del Cuzco y quizás más tarde en la de Lima. La disposición de los soportes es exactamente igual en las dos catedrales, pites en la de Puebla son medias muestras que se continúan en el íntrados de los arcos, a semejanza de la catedral mexicana, en tanto que en la del Cuzco son simplemente pilastras con su entablamiento $y$ que al prolongarse forman los arcos.

Todas estas semejanzas indudablemente nos llevan a suponer que si Becerra no fué el autor exclusivo de ambas catedrales, sí tomó parte en ellas. Para mí, el enorme interés de la catedral de Cuzco radica en que pude darme cuenta, al visitar este templo maravilloso, de cómo hubiera sido la catedral de Puebla si el proyecto original se lleva a cabo. Hubiera sido nuestro templo poblano, no tan semejante como es hoy a la catedral de México, sino muty parecido a la catedral cuzqueña, un poco más alto $y$ un poco más grande.

Ojalà que nuevos datos encontrados en archivos vengan a aclarar definitvamente este punto y a hacernos ver la parte que tuvo en ambas obras el notable arquitecto Francisco Becerra. Mientras esto acontece, rindámosle ahora el homenaje de nuestro agradeciniento por haber llenado nuestros paises de templos magnificos y haber realizado una especie de unión entre la arquitectura mexicana del siglo XVI y la que floreció entonces en el admirable virreinato del Perú. 


\section{B I B L IOGRA I A}

Noticias de los Arquitectos y Arquitectura de España deste su restauración, por el Exmo. señor don Eugenio Llaguno y Amirola, ilustradas y acrecentadas con notas, adiciones $y$ documentos por don Juan Agustín Ceán-Bermúdez.-Madrid, en la Imprenta Real.-Año de 1829.-Cuatro volúmenes.

Mario J. Buschiazzo. La Arquitectura Colonial del Cuzco.-Buenos Aires, 1836.

Luis E. Valcátcel. Cuzco, Capital Arqueológica de Sudamérica, 1539-1934,-Publicación del Banco Italiano.--Lima.

"Iglesias de México". Volumen VI. La Arquitectura Religiosa de la Nueva España durante el siglo XVI, por Manuel Toussaint. México. 1927. 